\title{
Expert assessments on evaluation of land use efficiency in municipalities of Latvia
}

\author{
Armands Auziņš, Ineta Geipele \\ Institute of Civil Engineering and Real Estate Economics, Faculty of Engineering Economics and Management of the Riga Technical University, \\ 6 Kalnciema Street, room-213, Riga, LV-1048, Latvia
}

\begin{abstract}
Systematic evaluation of land use efficiency allows justifying that the land resources are used for the public benefits. Accordingly, the support for a decision-making at municipal land management level could be provided and the land use in better and more efficient way promoted. The aim of the research is to explore and discuss the results of the expert assessments on necessity and possibilities for evaluation of land use efficiency in the municipal territories of Latvia. The data analysis of expert assessments follows basically a quantitative methodology. Therefore, the sociological research method, the analysis and synthesis, the logical-constructive and graphical methods mainly are used for the research. The findings of the study show the existing approaches for gathering and administrating the information about necessary changes in a functional land-use zoning, as well as the experts' view on the indicator sets and its relative significance to be applied for evaluation of land use efficiency and the evaluation process in a whole.
\end{abstract}

Keywords: Expert assessments; evaluation; land use; efficiency; Latvia.

\section{Introduction}

The rational use of land resources and land use monitoring has become topical all ower the world. Assessing the land use measures systematically is an essential procedure in providing sustainable land management practice [1]. Municipalities take a responsibility on implementation of land policy and land use management measures in their administrative territories in Latvia, thus may be considered as central linkage between the set of national priorities and land users' interests. Efficiency criteria and indicators are broadly applied for sustainability analysis in urban environments [2-3]. Land use efficiency (LUE) can be evaluated by using a methodological framework that includes both selected methods and developed system of appropriate indicators [4-5]. Therefore, assessed specific indicator sets are selected and applied for evaluation of land use outcome ascertaining the quantitative and qualitative land-use caused changes.

LUE has to be assessed by identifying its qualitative changes in dynamics in the process of land-use, by comparing the changes of the result or effect of land use to the changes in resources utilised for achieving of the effect. Zavadskas et al. (2007), by applying the specific multipurpose evaluation method and indicator system, set the priorities in residential areas for assessment of sustainable urban development [6]. LUE as a condition for sustainable development determines the need to use the values of human and land resources in such a way that it would contribute to the socio-economic development, which would constantly improve the efficiency of consumption of available resources in the public interest without compromising the ability to regenerate of the natural resources [1].

By exploring integrated land use management development trends [7], it is recognised that specifically in this area the legal and economic content of land management has to be identified and appraised, because the preconditions for monitoring of the use of land resources and efficiency increase on the level of local governments have to be determined [8]. Thus, at municipal level decisions are adopted and implemented relating to the land use and building regulations and investments into the development of real estate and civil infrastructure [9-10], as well as means are allotted for the protection of land resources and ensuring of the opportunity to regenerate developing sustainable communities [11].

Expert assessments are applied to process and use data obtained with the help of experts. These data have some subjectivism. Expert assessments are used in the sciences, most often in the mathematic modelling of systems, in the

Corresponding author: Armands Auziņš. E-mail address: armands.auzins@rtu.lv

http://dx.doi.org/10.3846/enviro.2014.106

(C) 2014 The Authors. Published by VGTU Press. This is an open-access article distributed under the terms of the Creative Commons Attribution License, which permits unrestricted use, distribution, and reproduction in any medium, provided the original author and source are credited. 
evaluation of a model's elements and its correlations, in criteria weighting, in decision-support systems, and in systems of multiple criteria analysis and optimisation [12-13].

\section{Aim and objectives: a case study in Latvia}

The aim of the study was to gather and analyse the expert assessments about the necessity and possibilities to evaluate the LUE in the territory of a municipality of Latvia. In order to carry out the study an expert survey was organised.

The objectives were set to find out: (1) the way of obtaining, gathering and managing the information on necessary changes in functional zoning of a territory; (2) the attitude of experts on evaluation of LUE in general; (3) the expert assessments on specific indicator sets of LUE and their relative significance (weights); (4) the existence and applications of established methodology (techniques, criteria, indicators etc.) for evaluation of LUE and development of the territory of a municipality; (5) the existing distribution of functional zones (land-use patterns) of municipal territory, identifying the territories where construction is set / is not set as primary usage.

\section{Research methodology}

In order to meet the aim and objectives of the research the LUE domain was explored and appropriate literature reviewed. 84 respondents - official land-use planners of 119 municipalities of the country were questioned, thus response factor of $71 \%$ was achieved. At the beginning of the survey the experts were informed about the aim, context and subject of the study. The direct questioning was carried out by using web online. 14 questions were included in the questionnaire to get the response according to the qualification of the experts [14]. Thus, the expert survey was organised by developing the selective census and including in it all general set [15-16]. Descriptive statistical method and statistical analysis was applied for gathering and analysing of the research outcome. The distribution of some responses was analysed by using linear regression [17], but using the textual analysis method of the qualitative research the analysis of responses to some openedtype questions was performed $[13,18]$.

\section{Results and discussion}

Assessing the qualification and competences of the experts regarding to land-use planning issues, it was concluded that most of the respondents (37\%) had a professional experience of $5-10$ years, the majority of them $(29 \%)$ were educated in spatial planning. $25 \%$ of the respondents were educated in architecture, but $20 \%$ - in economics. $99 \%$ of the respondents had a higher education.

When planning the development of a territory and implementing the development plans the information about necessary changes in functional zoning of a territory is gathered and analysed. During the survey it was found out: how does the information about necessary changes in functional zoning of a territory is gathered? The absolute majority of experts (95\%) recognised that the information was collected occasionally from the applications of inhabitants and entrepreneurs. The percentage of rest responses showed that the information was gathered in more organised way, for instance, by organising both periodic social survey and targeted seminars.

In order to facilitate the professional activities of land-use planners when planning the spatial developments, it is important to establish a common approach in organising the public participation and elicit views on preferred land use and development in appropriate territories. During the survey it was found out: Is there developed a common application form in the municipality for gathering the opinions of residents on preferred development / changes in functional zoning of a territory? The results of survey showed that an absolute majority of respondents (79\%) indicated that such a form was not developed, but it is needed. While $12 \%$ of respondents indicated to the fact that such a form was developed and is being used. $9 \%$ of respondents believed that a common application form was not developed and it is not necessary. As the reasons that the form was not developed were listed: small number of applications, small municipality, concerns about incompetence of residents, variability of interests, etc.

Exploring the documents of spatial development planning and guidelines, including designed municipal development programmes, it was concluded that often among the directions of planned development the objectives: to promote the rational usage of a territory and to improve the efficiency of land resources' use was mentioned. Therefore, during the survey it was asked: Is there developed the techniques for determining the LUE in the municipality? The obtained results, see Figure 1(a), indicated to the overwhelming necessity for such a techniques $(94 \%)$, including: $13 \%$ of respondents indicated that the techniques exist, but they are insufficiently well; $81 \%$ of respondents indicated that such a techniques were not developed, but they would be necessary. Only $2 \%$ of respondents answered that the appropriate techniques exist. $4 \%$ of respondents indicated that the techniques were not developed and they are not necessary, thus as the main reasons were listed: disorder of spatial planning process, caused restrictions of ownership and land use rights, productivity dependence of agricultural lands on allocation and evaluation. 


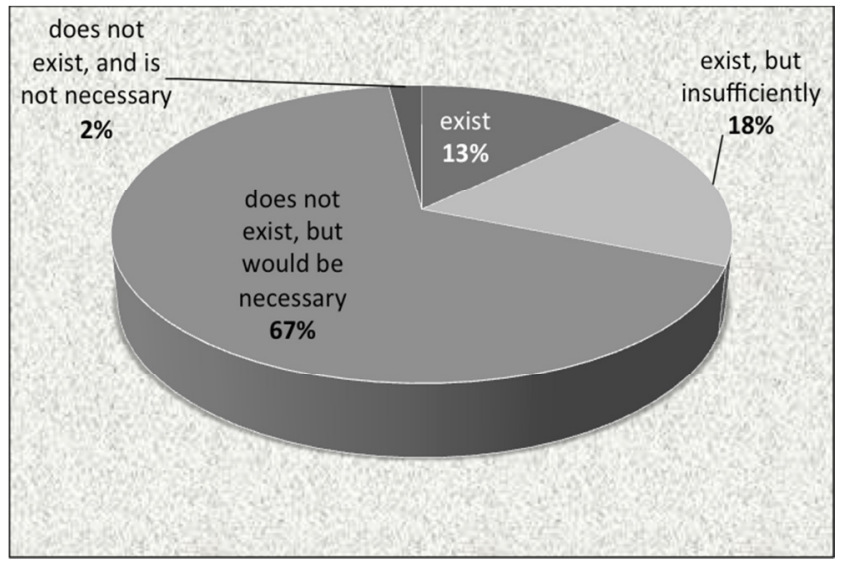

(a)

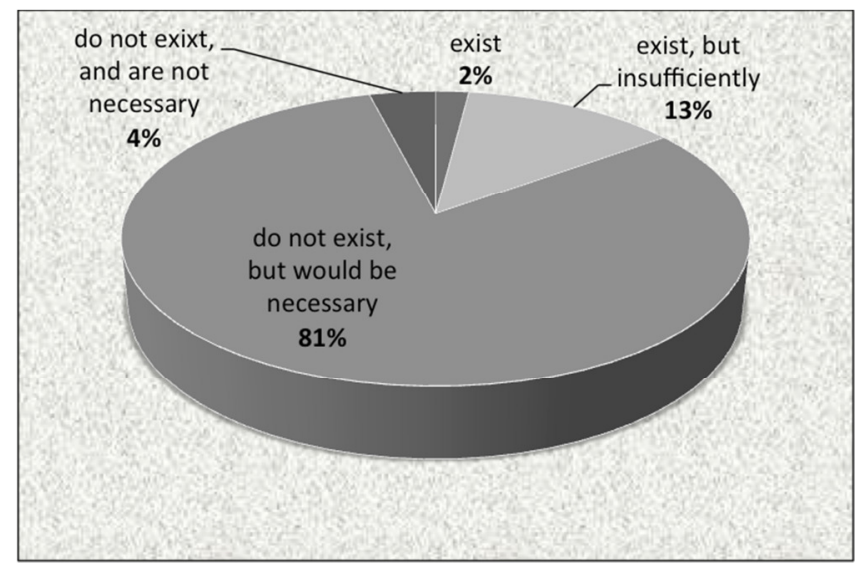

(b)

Fig. 1. Topicality for determination of LUE (a) and the need for an indicator system and monitoring of the spatial development (b)

Monitoring of the spatial development often is provided if either determining the implementation arrangement of local spatial plans and detailed plans or establishing and administering an indicator system for supervision of spatial development. A municipal development programme is concerned also with its action plan and the supervision and evaluation arrangement of the implementation. This arrangement includes the resulting indicators and a supervisory reporting [14]. During the survey it was found out: Is there established the indicator system that would be aimed at monitoring of the spatial development in the municipality? The majority of respondents (67\%) confirmed that the indicator system was not established yet, which would be aimed at monitoring of the spatial development, but it would be necessary, see Figure 1(b). Absolute minority of respondents (2\%) believed that such a system was not introduced, but it is not necessary at the municipal management level, mainly because of lack of capacity (manpower), therefore the indicator system should be developed at national level. $18 \%$ of surveyed experts recognised that, although such a system was established, it is insufficiently well. While $13 \%$ of experts recognised that appropriate indicator system was established.

The proportion of respondents (31\%), which used the developed indicator system for monitoring and evaluation of the spatial development, see Figure 1(b), was asked: Does the developed indicator system help to clarify the efficiency of land resources' usage? A half of this proportion considered that the developed system does not help to clarify the efficiency of land resources' usage in the municipality. As the reasons of this were listed, for instance, selection of general indicators, availability of incorrect and obsolete data, efficiency indicators are not included in the system, lack of objective indicators etc. Accordingly, the mentioned reasons indicate to the gaps in existing methodological solutions.

The experts were asked to evaluate the indicator sets that were selected and analysed during an initial research [1]. During the survey it was found out: What are the preferences of the experts regarding to indicator sets that can be applied for evaluation of LUE when developing the indicator system? Therefore, the percentage of expert preferences indicated to the indicator sets according to their relative significance, see Figure 2: the economic indicators (32\%), environmental quality indicators $(19 \%)$, social indicators $(16 \%)$, ecological indicators $(13 \%)$, statutory regulation indicators $(11 \%)$, and administrative management indicators $(9 \%)$.

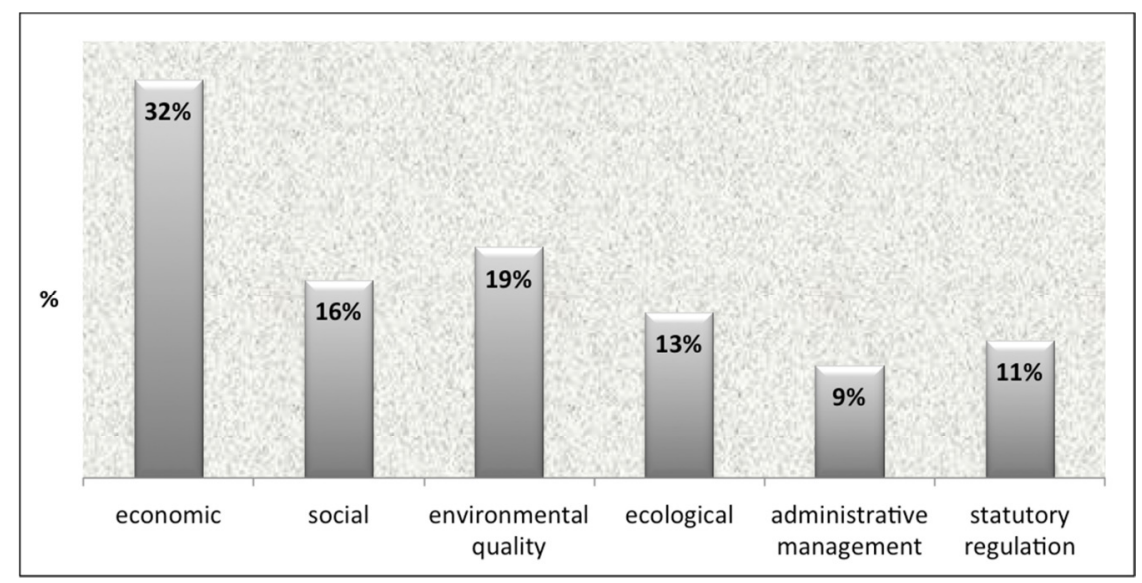

Fig. 2. Indicator sets according to their relative significance

As the initial analysis indicated to variability of the influencing factors of the land-use outcomes and coincident influence of these factors to the LUE [1], the experts were asked: What are the preferences regarding to integrated indicators that can be applied for evaluation of LUE when developing the indicator system? Accordingly, the percentage of 
expert preferences indicated to the integrated indicators considering their relative significance, see Figure 3: the socioeconomic indicators (47\%), environmental-ecological indicators $(33 \%)$, and administrative-regulatory or institutional indicators $(20 \%)$.

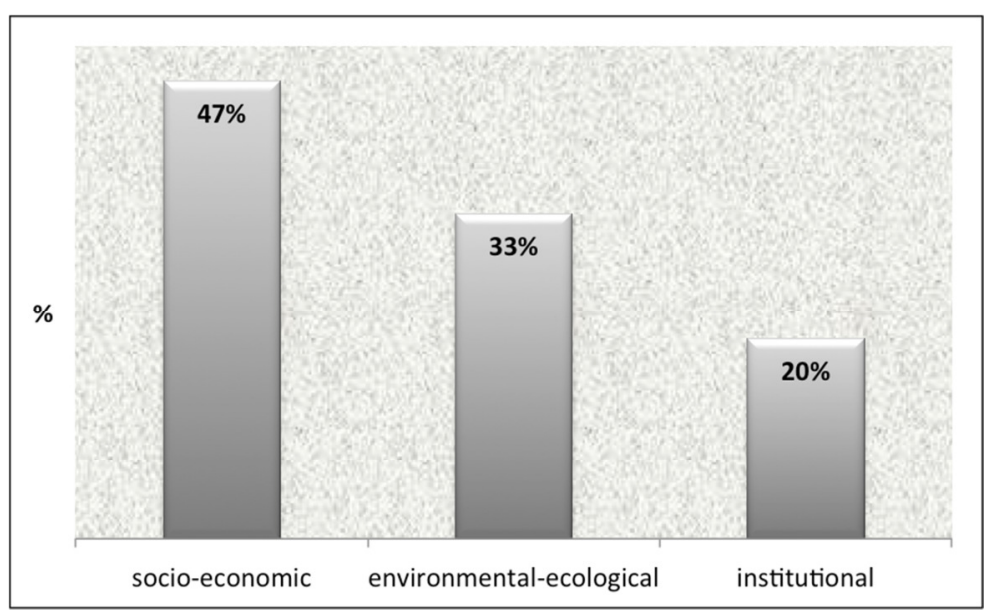

Fig. 3. Integrated indicators according to their relative significance

In order to obtain the confirmation on the extent to which the assessment of relative significance of the integrated indicators (\%) depends on the functional zoning of a municipal territory (\%), the statistical analysis by using linear regression method was carried out. This functional zoning, more specifically - systematically allocated various land-use patterns, is differentiated by two criteria: (1) the territories, where a construction is set as primary usage; and (2) the territories, where a construction is not set as primary usage. The analysis showed that there is no close interrelation between both assessment and zoning. Therefore, it was concluded that the dominance of existing land resources of a municipal territory if considering the functional zoning, did not affect the assessment of experts on relative significance of socioeconomic and environmental-ecological indicators. For instance, it was not confirmed that the experts representing the municipal territories, where a construction did not dominate, would higher assess the significance of environmentalecological indicators.

In order to identify the attitude of the respondents toward a method for evaluation of LUE, the experts were asked to express their opinions on needs and possibilities for evaluation of LUE and justification of decision-making regarding to land use in better and more efficient way. In general, the analysis of experts' responses on opened-type questions showed: a positive attitude (77\%), a neutral attitude (22\%), including those, who did not expressed their view at all, and a negative attitude (1\%). Two criteria - the necessity and the feasibility were selected as a result of the performed analysis, see Table 1. Accordingly, there was identified in the survey: What are the needs and what circumstances indicate on possibilities?

Table 1. The outcome of the analysis of experts' opinions

\begin{tabular}{|c|c|}
\hline Necessity $\rightarrow$ & $\leftarrow$ Feasibility \\
\hline $\begin{array}{l}\text { - An analysis and assessment of existing situation from the point of } \\
\text { view of economic return } \\
\text { - Objective response to the public opinion, basis for either refusal } \\
\text { or acceptance of the spatial development initiative } \\
\text { - Advantages of an uniform system within common land policy } \\
\text { framework, implementation of land policy } \\
\text { - Improvement of municipal activities, facilitation of professionals' } \\
\text { - } \text { Pork and preparation of ordinances } \\
\text { interdisciplinary approach } \\
\text { - Issuing of methodology or regulations } \\
\text { - Differentiated criteria of evaluation depending on a land-use } \\
\text { - } \text { pattern } \\
\text { - Aupport of decision-making process } \\
\text { - Facilitation of investment flow to the territory } \\
\text { - Detailed territorial studies and sustainable use of land resources } \\
\text { - Successful realisation of municipal development programmes and } \\
\text { - Supplial development plans } \\
\text { - Regular social survey and analysis of evaluation indicators of land } \\
\text { - Evaluation of land-use intensity and management quality } \\
\text { - Logical and step-by-step making of development decisions }\end{array}$ & $\begin{array}{l}\text { - Complicated co-operation among different authorities and burdened } \\
\text { data availability } \\
\text { - The issues of professionals' competence and limited access to } \\
\text { information } \\
\text { - Complicated process that needs a specific knowledge and additional } \\
\text { information } \\
\text { - Gathering of comparable dynamic data sets for longer period of time } \\
\text { - Coccording to appropriate methodology } \\
\text { - development } \\
\text { - Mistakes and gaps in the process of land-use planning } \\
\text { - Constraints in evaluation of private ownership } \\
\text { - Unevenly usage of land areas } \\
\text { - Diverse experiences in planning and evaluation of spatial development } \\
\text { - Development of priority sectors and support for use of land resources } \\
\text { - Deficient binding regulations, complicated course and the results of the } \\
\text { land reform } \\
\text { - Economic activity and land usage often do not comply with the } \\
\text { - Thunicipal functions } \\
\text { - Variability of socio-economic situation } \\
\text { - Insufficiently discussed issues of evaluation of LUE in a municipality } \\
\text { - The results of an evaluation do not ensure the changes } \\
\text { - The impact of lobbying on decision-making }\end{array}$ \\
\hline
\end{tabular}


The outcome of the analysis of experts' opinions in Table 1 clearly indicates to rather great challenges for future activities in the land-use management field in Latvia. The needs and possibilities were expressed critically and profoundly. The results of the analysis indicate the use of original method of analysis applying two criteria - the necessity and the feasibility.

\section{Conclusion}

The results of expert survey demonstrate the need for municipalities to develop and implement a common approach to obtaining, collection and evaluation of information on the situation in respect to the alterations, necessary in the functional zoning of the territory, as well as to develop and implement a common methodology for evaluating the LUE at the municipal level.

The competence of the experts, i.e. knowledge and experience, allows evaluating the versatility and complexity of activities in spatial development planning and land-use management. The results of the study indicate the need for training seminars or special courses for municipal specialists on evaluation of LUE, data maintenance and collection, information processing, and the analysis and administration of dynamic data series.

By evaluating the procedure and results of expert survey, important issues to be clarified in the future by organizing studies of a qualitative character, thus specific expert interviews in working groups should be carried out. For example, by evaluating the LUE on the territory of a specific municipality, the working group shall determine the available and applicable indicators and their relative significance (weights), as well as assess and clarify LUE evaluation model.

As practical benefits of the study can be considered challenges for evaluation of LUE at the municipal level, development of indicators used in the assessment system, the percentage in distribution of the indicators, which has to be taken into account in determining the weights of the indicators, as well as establishing of a system for information gathering and monitoring of spatial development planning and plan implementation in order to support decision-making process for land use in the best possible and most efficient way.

\section{References}

[1] Auzins, A.; Geipele, I.; Stamure I. 2013. Measuring Land-Use Efficiency in Land Management, Advanced Materials Research, Materials and Measurement 804: 205-210. http://dx.doi.org/10.4028/www.scientific.net/AMR.804.205

[2] Jarrar, O. M.; Al - Zoabi, A. Y. 2008. The applicability of sustainable city paradigm to the city of Jerusalem: Criteria and indicators of efficiency, Building and Environment 43(4): 550-557. http://dx.doi.org/10.1016/j.buildenv.2007.01.025

[3] Medineckiene, M.; Turskis, Z.; Zavadskas, E. 2011. Life-cycle analysis of a sustainable building, applying multi-criteria decision making method, In $8^{\text {th }}$ International Conference Environmental Engineering 3: 957-961.

[4] Chen, S.; Liu, Y.; Chen, C. 2007. Evaluation of Land-Use Efficiency Based on Regional Scale - A Case Study in Zhanjiang, Guangdong Province. Journal of China University of Mining \& Technology 17(2): 215-219. http://dx.doi.org/10.1016/S1006-1266(07)60075-3

[5] Auziņš, A.; Geipele, S.; Geipele, I. 2014. New indicator system for evaluation of land use efficiency. $4^{\text {th }}$ International Conference on Industrial Engineering and Operations Management (IEOM), 2285-2293. CD version. ISBN: 978-0-9855497-1-8; ISSN: $2169-8767$.

[6] Zavadskas, E.; Viteikienė, M.; Šaprauskas, J. 2007. Sustainable development assessment of cities and their residential districts, Ekologija 53: 49-54.

[7] Williamson, I; Enemark, S; Wallace, J; Rajabifard, A. 2010. Land Administration for Sustainable Development. ESRI Press Academic Press, Redlands, California, USA, p. 487.

[8] Vanags, E.; Vilka, I. 2005. Pašvaldību darbība un attīstība [Performance and development of local governments]. Riga: University of Latvia, p.384.

[9] Dai, L.; Zhao, X.; He, H. S.; Deng, H.; Yu, D.; Zhou, L.; Wu, S. 2008. Evaluating land-use suitability of an industrial city in northeast China, International Journal of Sustainable Development \& World Ecology 15(4): 378-382. http://dx.doi.org/10.3843/SusDev.15.4:14

[10] Griškevičiūte-Gečiene, A. 2010. The evaluation of investment projects within the territory of development, Transport 25(2): $203-214$. http://dx.doi.org/10.3846/transport.2010.25

[11] Maliene, V.; Durney-Knight, N.; Sertyesilisik, B. 2011. Developing sustainable communities: comparative case study from North West of England, in $8^{\text {th }}$ International Conference Environmental Engineering 3: 948-956.

[12] Turban, E. 1995. Decision support systems and expert systems. $4^{\text {th }}$ ed, Prentice Hall.

[13] Markovičs, Z. 2009. Ekspertu novērtējumu metodes [Expert assessment methods]. Riga: RTU Publishing House, p. 110.

[14] CM. 2012. Cabinet of Ministers of the Republic of Latvia. Regulations No. 711. - Accessed: 8 January, 2014. Available from internet: http://www.likumi.lv

[15] Stark, R.; Roberts, L.; Corbett, M. 2002. Contemporary Social Research Methods. Wadsworth Publishing, p. 304.

[16] Gomm, R. 2008. Social Research Methodology. A Critical Introduction. Palgrave Macmillan, p. 448.

[17] McDaniel, C.; Gates, R. 2013. Marketing research. John Wiley \& Sons Inc., p. 736.

[18] Creswell, J. W.; Plano Clark, V. L. 2011. Designing and Conducting Mixed Methods Research. SAGE Publications, Inc., p. 488. 